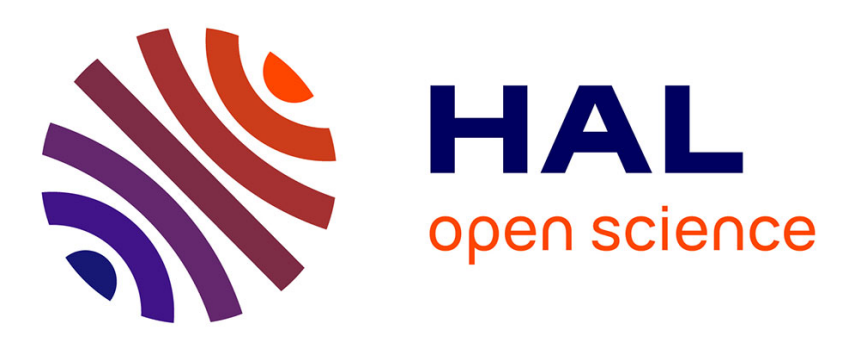

\title{
Production of whey protein aggregates with controlled end-use properties
}

Perla Relkin, Clémence Françoise Bernard, Thierry Meylheuc, Jean Vasseur, Francis Courtois

\section{- To cite this version:}

Perla Relkin, Clémence Françoise Bernard, Thierry Meylheuc, Jean Vasseur, Francis Courtois. Production of whey protein aggregates with controlled end-use properties. 27. world dairy congress and world dairy summit of the international-dairy-federation, Oct 2006, Shangai, China. pp.337-348, 10.1051/lait:200721 . hal-01194953

\section{HAL Id: hal-01194953 \\ https://hal.science/hal-01194953}

Submitted on 7 Sep 2015

HAL is a multi-disciplinary open access archive for the deposit and dissemination of scientific research documents, whether they are published or not. The documents may come from teaching and research institutions in France or abroad, or from public or private research centers.
L'archive ouverte pluridisciplinaire HAL, est destinée au dépôt et à la diffusion de documents scientifiques de niveau recherche, publiés ou non, émanant des établissements d'enseignement et de recherche français ou étrangers, des laboratoires publics ou privés. 


\title{
Production of whey protein aggregates with controlled end-use properties
}

\author{
Perla RELKIN $^{\mathrm{a} *}$, Clémence BERNARD ${ }^{\mathrm{a}, \mathrm{b}}$, Thierry MEYLHEUC ${ }^{\mathrm{c}}$, Jean VASSEUR $^{\mathrm{b}}$, \\ Francis COURTOIS ${ }^{b}$ \\ ${ }^{\text {a } U M R ~} 1211$ (AgroParisTech, CNAM, INRA) \\ b UMR 1145 (AgroParisTech, CEMAGREF, INAPG, INRA) \\ ${ }^{\text {c }}$ UMR 763 (AgroParisTech, INRA), 1 avenue des Olympiades, 91744 Massy, France
}

\begin{abstract}
We studied the structural behaviour and foaming properties of whey proteins under the effects of spray-drying in a co-current configuration. We used two different inlet/outlet air temperatures $\left(170 / 85^{\circ} \mathrm{C}\right.$ or $260 / 138{ }^{\circ} \mathrm{C}$, respectively), the other operating conditions being unchanged. Using different characterisation techniques, we showed that both whey proteins (WP-P 85 and WP$\mathrm{P}_{138}$ ) which were submitted to hydro-thermal treatments under mild and high air processing conditions behaved differently from untreated proteins (WP-L). As expected, WP- ${ }_{138}$ powder exhibited lower moisture and free lactose contents, a higher particle internal porosity, and a thinner particle wall thickness than the WP- $\mathrm{P}_{85}$ powder. The conformational stability of whey proteins, obtained by dilution of untreated whey proteins (WP-L) and dispersions of the two spray-dried powders (WP$\mathrm{P}_{85}$ and WP- $\mathrm{P}_{138}$ ), were compared. Whey proteins in the WP- $\mathrm{P}_{138}$ powder showed a red-shift in the tryptophan emission wavelength, the appearance of a newly created fluorescent compound at $420 \mathrm{~nm}$, contrary to untreated and WP- $\mathrm{P}_{85}$ whey proteins. In addition, we observed formation of a higher proportion of covalently-bound aggregates $\left(11 \%\right.$ in WP- $\mathrm{P}_{138}$, instead of $5 \%$ in WP- $\left.\mathrm{P}_{85}\right)$ and a decrease in conformational stability against re-heating ( $\sim 50 \% \mathrm{~s}$ in WP-P ${ }_{138}$, instead of $\sim 30 \%$ in WP- $\mathrm{P}_{85}$ ) compared with untreated WP-L solution. Finally, combination of continuous measurements of foam volume (by an on-line video camera) and liquid (by conductivity) entrained in a column foam during its formation by air injection, in parallel with automatic acquisition of videofoam images during the destabilisation step, showed that solution of WP- $\mathrm{P}_{138}$ spray-dried powder, obtained using the highest air temperature conditions, has higher foaming properties than WP-P 85 and WP-L solutions.
\end{abstract}

whey protein / spray-drying / denaturation / aggregate / foam

\begin{abstract}
摘要 - 通过控制终产品的特性生产乳清蛋白凝聚物。本文研究了逆流喷雾干燥对乳清 蛋白结构和发泡性的影响。在其他工艺参数不变的条件下, 分别采用两种不同的内外气流 温度 $\left(170 / 85^{\circ} \mathrm{C}\right.$ 或 $\left.260 / 138^{\circ} \mathrm{C}\right)$ 。由于采用不同的处理工艺, 分别经过中温和高温热处理后 的两种乳清蛋白 (WP-P 85 和 WP-P ${ }_{138}$ ) 性质不同于未处理的乳清蛋白 (WP-L)。正如我们期 望的, 与 WP-P 85 蛋白粉相比, WP-P $\mathrm{P}_{138}$ 蛋白粉的水分含量低、不含乳糖,颗粒内部的孔隙度 较大、颗粒孔壁薄。比较了未处理乳清蛋白稀释液和两种喷雾干燥的乳清粉 (WP-P 85 和 WP-P $\mathrm{P}_{138}$ )分散液的构象稳定性。与未处理的乳清蛋白和 WP-P 85 乳清蛋白不同, WP-P 138 粉 中乳清蛋的色氨酸发射波长向红的二段移动, 在 $420 \mathrm{~nm}$ 出现了一个新的苂光化合物。此 外, 与未处理的乳清蛋白相比, 喷雾干燥的乳清呈现较高比例的以共价键结合形成的凝聚 物 (WP- $\mathrm{P}_{138}$ 为 $11 \%, \mathrm{WP}-\mathrm{P}_{85}$ 为 5\%), 但是再次加热后其构象稳定性下降 (WP- $\mathrm{P}_{138}$ 约下降 $50 \%$,
\end{abstract}

* Corresponding author (通讯作者): perla.relkin@agroparistech.fr 
WP- $P_{85}$ 约下降 $\left.30 \%\right)$ 。最后, 将气体经过一个多孔的喷酒器鼓入含有蛋白质溶液的柱子里, 通 过一个在线摄像机自动截获泡沫形成的图像, 实验证明在最高气流温度下喷雾干燥获得的 WP-P ${ }_{138}$ 溶液比 WP-P 85 和 WP-L 溶液具有较大的发泡性。

\section{乳清蛋白 / 喷雾干燥 / 变性 / 凝聚 / 发泡性}

Résumé - Production d'agrégats de protéines sériques à propriétés d'usage. Nous avons étudié l'influence du séchage par pulvérisation, en co-courant, sur le comportement structural et les propriétés moussantes de protéines de lactosérum. Les poudres ont été obtenues en utilisant des températures d'entrée et sortie d'air différentes $\left(170 / 85^{\circ} \mathrm{C}\right.$ et $260 / 138^{\circ} \mathrm{C}$, respectivement), les autres conditions opératoires étant inchangées. Par application de différentes techniques de caractérisation, nous avons montré que les protéines (WP- $\mathrm{P}_{85}$ et WP- $\mathrm{P}_{138}$ ) qui ont subi des traitements hydrothermiques à température d'air modérée et sévère, respectivement, se comportent différemment des protéines (WP-L) contenues dans les solutions avant séchage. Comme attendu, la poudre contenant les protéines WP- $\mathrm{P}_{138}$ présente des taux d'humidité et de lactose libre plus faibles, un taux de porosité interne plus important, et une épaisseur de paroi plus faible. L'étude spectrofluorimétrique des protéines, contenues dans des dispersions dans l'eau distillée des poudres issues des deux conditions de séchage, indique que pour les protéines WP- $\mathrm{P}_{138}$, et contrairement aux protéines WP-L et WP- $\mathrm{P}_{85}$, la longueur d'onde maximum d'émission de fluorescence du tryptophane présente un déplacement vers le rouge, ainsi que l'apparition de nouveaux composés qui fluorescent avec une longueur d'onde maximum d'émission à $420 \mathrm{~nm}$. D'autre part, nous avons observé une plus forte proportion d'agrégats covalents $\left(11 \%\right.$ pour WP- $\mathrm{P}_{138}$ au lieu de $5 \%$ pour $\left.\mathrm{WP}-\mathrm{P}_{85}\right)$, ainsi qu'une diminution plus importante de la stabilité conformationnelle vis-à-vis de la chaleur pour WP-P $\mathrm{P}_{138}$ $(\sim 50 \%)$ que pour WP-P $\mathrm{P}_{85}(\sim 30 \%)$. Finalement, la mesure in situ des volumes de mousse (camera video) formée par injection d'air dans une colonne et de liquide sous la mousse (conductivité) après arrêt de l'injection de gaz, effectuée parallèlement à l'acquisition automatique d'images de la mousse, ont montré que les protéines WP- $\mathrm{P}_{138}$ ont de meilleures propriétés moussantes que les protéines WP-P 85 et WP-L.

protéine de lactosérum / séchage par dispersion / dénaturation / agrégat / mousse

\section{INTRODUCTION}

In the milk industry, whey represents a large amount of by-product from cheese production, and heating is often used for its further processing such as concentration, protein fractionation, demineralisation and drying. In their native conformational state, whey proteins have a globular tertiary structure which is stabilised by non-covalent interaction forces (hydrogen, ionic and hydrophobic bonding) and also by covalent cross-linking. Among whey proteins, $\beta$-lactoglobulin (major component), bovine serum albumin (BSA), and immunoglobulin $\mathrm{G}$ (IgG) contain both disulphide bonds and free sulphydryl groups, while $\alpha$-lactalbumin (the second most important whey protein in terms of weight ratio), contains disulphide bonds but no free thiol group [17]. For several years, globular proteins have been the focus of numerous studies, not only for their nutritional amino-acid balance, but also for their functional properties in food systems which were shown to be related to their conformational changes [6-8, 12, 13, 17, 22-26]. Most previous studies indicated that the conformational stability of whey proteins is greatly dependent on their intrinsic and extrinsic physico-chemical parameters, such as protein composition and concentration, $\mathrm{pH}$, ionic strength and time-temperature of heating conditions

During spray-drying, liquid droplets are atomised and evaporated when in contact with hot air. And, following this hydro-thermal path their dissolved solids are more and more saturated, leading to formation of a solid crust on the droplet surface and dried particles with different qualities [14,21]. Quality of milk powders 
produced by spray-drying was evaluated in regard to the effects of the product flow rate in co-or counter-current configuration, atomisation speed and inlet air temperature on powder density, particle diameter and flowability $[3,5]$. Other studies focused on the effects of spray-drying on changes in lactose, fat and protein surface composition of milk particles, changes in whey protein denaturation and association with casein during different steps in production of milk powders, including concentrate heating before drying $[15,19,20]$ and product feed concentrations [1]. In most of these studies, the effects of drying on protein structural changes were examined in milk powder whose proteins were assumed to have not been affected by spray-drying. Recently [2], a simple model based on mass and energy balances between co-current drying air and whey protein droplets was applied to predicting particle hydro-thermal paths in the drying chamber as functions of various operating drying conditions. Measured air outlet temperatures and water contents were compared with those predicted by the model, and used to discuss the effects of spray-drying on changes in a whey proteinrich product.

In the present study we focused on determination of the degree to which spray-drying of a protein-rich product, in a co-current configuration, can lead to heatinduced denaturation-aggregation with effects on end-use properties.

\section{MATERIALS AND METHODS}

Spray-drying of a whey product ( $\mathrm{pH}$ 6.7) prepared by micro-filtration of skimmed milk (Ingredia, Arras, France) was performed in a pilot-scale dryer (Niro Minor pilot, GEA, Niro Atomizer, Parma, Italy), with an atomiser rotary disc type, and feeding in drying air in a co-current configuration [2]. In this study we compared effects on whey protein structural changes upon spray-drying at two air inlet temperatures $\left(170\right.$ and $\left.260^{\circ} \mathrm{C}\right)$, the other operational variables such as the product flow rate $\left(3.4 \mathrm{~kg} \cdot \mathrm{h}^{-1}\right)$ and the air flow rate $\left(0.029 \mathrm{~kg} \cdot \mathrm{s}^{-1}\right)$ being unchanged.

\subsection{Protein characterisation}

The whey protein concentrate (WPC) was characterised before and after drying for its dry matter and protein composition (Tab. I). The weight percentages of dry matter and ashes were obtained by heating the protein-rich samples at $105^{\circ} \mathrm{C}$ for the period needed to reach a constant weight, and at $550{ }^{\circ} \mathrm{C}$ for $5 \mathrm{~h}$, respectively. The lactose content was obtained by application of the Boehringer Lactose/DGalactose kit (Boehringer Mannheim, Meylan, France), and the total protein content and protein solubility were determined, after powder dispersion in distilled water ( $1 \% \mathrm{wt}$ and gently stirring for $2 \mathrm{~h}$ ), by Kjeldahl analysis of protein solutions and their supernatants obtained after centrifugation $(15000 \times \mathrm{g}, 60 \mathrm{~min}$, $15^{\circ} \mathrm{C}$ ). Polyacrylamide gel electrophoresis (PhastSystem apparatus, Pharmacia Biotech-Orsay, France) in dissociative conditions (SDS-PAGE) was used for evaluation of the relative proportions of $\beta-\lg$ and $\alpha$-la monomers and covalently-bound aggregates [24]. We used a $20 \% \mathrm{w} / \mathrm{w}$ homogeneous gel concentration (Pharmacia Biotech), and a molecular weight standard (Low Molecular Weight Electrophoresis Calibration Kit/ Pharmacia) for identification of protein bands. Protein samples were diluted 1:1 with SDS PAGE sample buffer $\left(20 \mathrm{~mol} \cdot \mathrm{L}^{-1}\right.$ Tris/ $\mathrm{HCl}-\mathrm{pH} 8.0$, $2 \mathrm{~mol} \cdot \mathrm{L}^{-1}$ EDTA and $5 \%(\mathrm{w} / \mathrm{w}) \mathrm{SDS}$ ) then heated for $5 \mathrm{~min}$ in a boiling water bath under stirring before being cooled in an ice bath. After separation, the gels were stained using $0.1 \%$ Coomassie blue (Phastgel Blue R-350, Pharmacia BiotechOrsay, France). The corresponding electrophoretic patterns were scanned (Image 
Table I. Characteristics of exiting powders from the drying chamber, depending on air inlet and outlet temperatures used for spray-drying of whey protein solution (22\% dry matter).

\begin{tabular}{lcc}
\hline Dried powders & WP-P & WP-P \\
\hline Dryer inlet air temperature $\mathrm{T}_{\mathrm{ai}}\left({ }^{\circ} \mathrm{C}\right)$ & 170 & 260 \\
Dryer outlet air temperature $\mathrm{T}_{\mathrm{ao}}\left({ }^{\circ} \mathrm{C}\right)$ & 85 & 138 \\
Outlet powder water content $\left(\mathrm{kg} \cdot \mathrm{kg}^{-1}\right)$ & 0.057 & 0.034 \\
$\mathrm{D}_{0.5}(\mu \mathrm{m})$ & $9.5 \pm 0.11$ & $10.0 \pm 0.00$ \\
$\varepsilon(\%)$ & 27.3 & 44.6 \\
\hline
\end{tabular}

Scanner, Pharmacia), and the relative protein concentrations were determined densimetrically (Image Master 1D, Pharmacia Biotech, Orsay, France).

\subsection{DSC measurements}

Protein conformational stability against heating was determined by using differential scanning calorimetry (Perkin Elmer DSC VII, USA), following the methodology described elsewhere [25]. Whey protein solution, WP-L (22\% dry matter) prepared by microfiltration from skim milk, was submitted to a heating cycle $\left(10^{\circ} \mathrm{C} \cdot \mathrm{min}^{-1}\right.$, from 10 to $\left.100^{\circ} \mathrm{C}\right)$ and the observed calorimetric parameters $\left(\mathrm{T}_{\mathrm{p}}\right.$, peak maximum deviation and $\mathrm{Q}_{\mathrm{cal}}$, overall heat involved during the peak transition) were compared with those obtained from dispersion at $22 \%$ dry matter of exiting powders (WP- $\mathrm{P}_{85}$ and $\mathrm{WP}-\mathrm{P}_{138}$ ) from the drying chamber.

\subsection{Fluorescence properties}

Fluorescence measurements were performed using a SLM AB2 Aminco Bowman spectrofluorimer (Chamarande, France). Tryptophan fluorescence properties of the three whey protein samples $(0.01 \%)$ were evaluated at 280/330 excitation-emission wavelengths. Observation of other fluorophore compounds was performed using
330/420 excitation-emission wavelengths and protein solutions at a higher protein concentration $(0.05 \%)$. The variation in the intensity photon flux, as a function of wavelength, was minimised by using a ratio amplifier mode, as specified by the manufacturer.

\subsection{Powder characterisation}

Particle size distribution of the different exiting powders from the drying chamber was measured by laser diffraction using the Malvern Mastersizer with powder feeder unit (Scirrocco 2000, Malvern Instruments SA, Orsay, France), used with the Malvern software for determination of particle median diameter values $\left(D_{50}\right)$. Particle density, $\rho_{\mathrm{p}}$, was measured using an Accupyc 1330 pycnometer (Micromeritiscs, Creil, France), whose principle is gas displacement. The percentage of internal porosity (non-accessible pores to air) was evaluated using the following equation:

$$
\varepsilon=\frac{\rho_{\mathrm{pg}}-\rho_{\mathrm{p}}}{\rho_{\mathrm{pg}}} \times 100
$$

where $\rho_{\mathrm{p}}$ and $\rho_{\mathrm{pg}}$ are the particle density of exiting powders from the drying chamber, before and after grinding.

Scanning electron microscopy (Jeol JSM5200 SEM, operating at $5 \mathrm{kV}$, Croissy sur Seine, France) was used for observation of the particle size and wall thickness. Powder samples, before and 
after grinding, were mounted on doublesided adhesive mounted on SEM stubs, and were coated with $\mathrm{Au} / \mathrm{Pd}$ in a sputter coater.

\subsection{Foaming properties}

Foaming properties of whey protein solutions were characterised using a foam analyser based on conductimetric measurements $[10,11,13,23]$. The foam was generated by sparging air $\left(15 \mathrm{~mL} \cdot \mathrm{min}^{-1}\right)$ into an initial volume of protein solution $(12 \mathrm{~mL})$ through a metallic porous disk (a sintered metal frit of $2 \mu \mathrm{m}$ pore size). The foaming ability was evaluated by the sparging time needed to reach a certain total of foam volume that was detected by an on-line camera, while the volume of liquid under the foam was measured by conductimetry. Foam formation and liquid drainage were analysed for $20 \mathrm{~min}$ with acquisition of images of air bubbles during the draining process.

The variation of conductivity performed at the base of the foam between two large electrodes, as a function of time $\left(\mathrm{C}_{\mathrm{t}}\right)$ and with reference to the conductivity of the buffered test solution $\left(\mathrm{C}_{\text {init }}\right)$, was used to calculate the volume of liquid in the foam column $\left(\mathrm{V}_{\mathrm{L}}\right)$, according to [10]

$$
\left.\mathrm{V}_{\mathrm{L}}(\mathrm{t})=\mathrm{V}_{\text {init }}\left[1-\mathrm{C}_{\mathrm{t}} / \mathrm{C}_{\text {init }}\right)\right]
$$

where $V_{\text {init }}$ is the volume of protein solution $(12 \mathrm{~mL})$ incorporated into the sparging chamber. Foaming capacity of protein solutions was evaluated by the air sparging time $\left(t_{0}\right)$ needed to form a certain volume of foam (around $40 \mathrm{~mL}$ ), by foam density value $\left(D_{\max }\right)$, immediately after the sparging time, $\mathrm{t}_{0}$, and $\mathrm{t}_{1 / 2}$, the time corresponding to half of the volume liquid retained by the foam bubbles

$$
\mathrm{t}_{1 / 2}=0.5\left(\mathrm{~V}_{\max }+\mathrm{V}_{\text {min }}\right) .
$$

All the air bubble images were shot with a camera (Philips ToUCam PCVC $750 \mathrm{~K}$ ) connected to the USB port of the computer located facing the bubbling column. Dedicated software was designed using IrfanView freeware to record pictures automatically every $20 \mathrm{~s}$ and save them in TIFF uncompressed format with a time stamp in its file name. To have the best possible pictures, the camera was located approximately $0.16 \mathrm{~cm}$ from the foaming column, at the middle of the height of the foam. The system was illuminated from the top with a $25 \mathrm{~W}$ bulb with a $45^{\circ}$ angle from the column axis. Two light deflectors were adapted on the column: one at the top and the other at the bottom. This method forced the light to go inside the column only, avoiding any reflections disturbing the acquisition.

\section{RESULTS AND DISCUSSION}

The protein-rich product was spraydried in a co-current configuration using two different values of air inlet temperatures, while the other processing parameters, such as the product flow rate and the air flow rate, were unchanged $\left(3.4 \mathrm{~kg} \cdot \mathrm{h}^{-1}\right.$ and $0.029 \mathrm{~kg} \cdot \mathrm{s}^{-1}$, respectively). Air outlet temperatures and physico-chemical characteristics of the two exiting powders are reported in Table I. It is seen that increasing the inlet air temperature from 170 to $260^{\circ} \mathrm{C}$ was accompanied by an increase in the outlet air temperature $\left(\sim 53^{\circ} \mathrm{C}\right)$ and a decrease in water content $(\sim 40 \%)$, in parallel with an increase in powder internal porosity $(\sim 40 \%)$. Images of spray-dried powders obtained by scanning electron microscope displayed a smooth surface and typical "skin-forming" behaviour resulting in hollow spheres (Fig. 1), with a wall thickness which appeared thinner for particles in the WP-P 138 sample, in parallel with a much higher internal porosity but close values of the average median particle size as determined by laser light scattering measurements (Tab. I).

The whey protein-rich products (WP$\mathrm{P}_{85}$ and $\left.\mathrm{WP}-\mathrm{P}_{138}\right)$, obtained at the two 

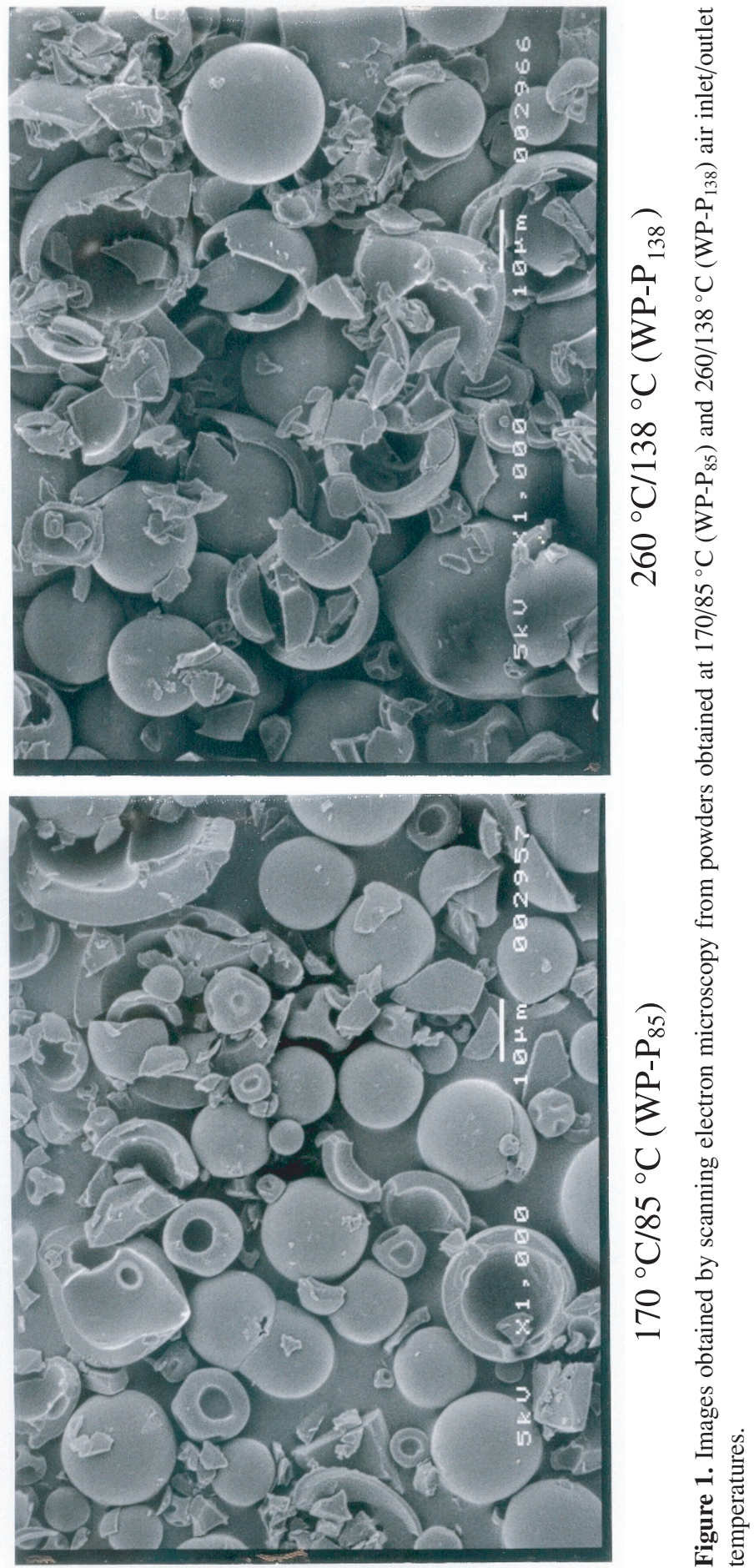
Table II. Dry matter composition (\% wt), protein solubility and protein composition of the proteinrich product.

\begin{tabular}{lrrr}
\hline Protein sample & WP-L & WP-P & WP-P \\
\hline \% Dry matter & $22.5 \pm 2.6$ & $94.2 \pm 1.6$ & $96.7 \pm 0.1$ \\
\% Ashes & $4.3 \pm 0.1$ & $4.10 \pm 0.0$ & $4.4 \pm 0.2$ \\
\% Lactose & $7.7 \pm 0.3$ & $7.10 \pm 0.20$ & $4.2 \pm 0.1$ \\
\% Proteins & $84.9 \pm 1.8$ & $87.4 \pm 3.0$ & $82.4 \pm 2.0$ \\
Protein solubility (1\%-pH6.7) & $97.1 \pm 1.2$ & $93.0 \pm 0.3$ & $85.0 \pm 0.7$ \\
Protein composition (\%) & & & \\
HMW A & $3.5 \pm 0.2$ & $4.5 \pm 0.5$ & $11.2 \pm 2.1$ \\
$\beta-\mathrm{lg}$ & $77.6 \pm 1.8$ & $74.0 \pm 1.2$ & $74.0 \pm 1.2$ \\
$\alpha-\mathrm{la}$ & $18.9 \pm 1.9$ & $19.3 \pm 0.7$ & $13.4 \pm 2.4$ \\
\hline
\end{tabular}

different air inlet temperatures (170 and $260^{\circ} \mathrm{C}$ ), were also characterised for their dry matter composition, protein solubility $(1 \%, \mathrm{pH} 6.7)$ and protein composition. The results reported in Table II indicate that drying using mild or high air temperatures was accompanied by changes in whey protein physico-chemical characteristics. Particularly, it is seen that spraydrying in a co-current configuration can lead to powders with decreasing values of protein solubility, concentration of free lactose and $\beta$-lg and $\alpha$-la monomers. This decrease in protein solubility and whey protein monomers was followed by formation of an increased proportion of high molecular weight covalently-bound whey protein aggregates $\left(>100 \mathrm{~kg} \cdot \mathrm{mol}^{-1}\right)$.

Local structural changes in whey proteins under the effect of spray-drying were evaluated using spectrofluorimetric measurements at $280 \mathrm{~nm}$ and $330 \mathrm{~nm}$ excitation wavelengths. The peak fluorescence intensity corresponding to tryptophan fluorescence decreased by approx. $27.5 \%$ and $17 \%$ for $\mathrm{WP}^{-\mathrm{P}_{138}}$ and $\mathrm{WP}-\mathrm{P}_{85}$, respectively (Tab. III), but the corresponding wavelength was close to $332 \mathrm{~nm}$ for both WP-L and WP-P ${ }_{85}$ samples, and close to $338 \mathrm{~nm}$ for WP-P 138 . The high Stokes' shift (from 332 to $338 \mathrm{~nm}$ ) observed for tryptophan fluorescence of the WP-P 138 sample, in parallel with a newly created fluorescence spectrum at $330 / 420 \mathrm{~nm}$ excitation and emission wavelengths, respectively, could be explained by changes in the whey proteins' tertiary structure from a compact one (native) to a denatured one [16]. This protein structure transition was accompanied by an increase in the exposure of initially buried hydrophobic residues to the aqueous medium, with creation of a new fluorophore compound, observed at $420 \mathrm{~nm}$, the maximum wavelength emission. This compound was attributed to formation of a Maillard product reaction under damaged effects of high air temperature [4, 18].

Thus, it appears that protein-rich liquid droplets, when in contact in the drying chamber with hot air for less than $15 \mathrm{~s}$, may be denatured and form covalently-bound aggregates (as shown by SDS-PAGE) and also new fluorophore compounds with maximum emission wavelength at $420 \mathrm{~nm}$.

Structural changes in whey proteins were also evaluated by differential scanning calorimetry (DSC) through determination of the energy $\left(\mathrm{Q}_{\mathrm{cal}}\right)$ involved in heat-induced transitions observed in protein solutions (22\% dry matter) before drying, and protein solutions obtained by dispersions in water of the dried powders. Examples of DSC curves obtained by heating from 10 to $100{ }^{\circ} \mathrm{C}$ at $10^{\circ} \mathrm{C} \cdot \mathrm{min}^{-1}$ of WP-L, WP-P ${ }_{85}$ and WP-P 138 are shown in Figure 2. They had a similar shape, with 
Table III. Spectrofluorimetric and calorimetric parameters obtained from three whey protein solutions. WP-L: whey protein sample before drying; WP-P 85 : whey protein sample spray-dried at $170 / 83^{\circ} \mathrm{C}$ air inlet/outlet temperatures; WP-P ${ }_{138}$ : whey protein sample spray-dried at $260 / 138{ }^{\circ} \mathrm{C}$ air inlet/outlet temperatures. $\mathrm{IF}_{330}$ and $\mathrm{IF}_{420}$ are peak fluorescence intensity at $280 / 330$ and $330 / 420 \mathrm{~nm}$ excitation and emission wavelengths, respectively, $\mathrm{T}_{\max }$ is the DSC peak maximum temperature and $\mathrm{Q}_{\mathrm{cal}}$ is the total DSC heat of reaction.

\begin{tabular}{lcrrc}
\hline & $\mathrm{IF}_{330}$ (u.a.) & $\mathrm{IF}_{420}$ (u.a.) & $\mathrm{T}_{\max }\left({ }^{\circ} \mathrm{C}\right)$ & $\mathrm{Q}_{\text {cal }}\left(\mathrm{J} \cdot \mathrm{g}^{-1}\right)$ \\
\hline WP-L & 240 & 12.2 & 979.3 & 13 \\
WP-L & 199 & 13.4 & 81.0 & 9.2 \\
WP-P $_{138}$ & 174 & 26 & 83.0 & 6.4 \\
\hline
\end{tabular}

a major peak transition located at around $80^{\circ} \mathrm{C}$ and a minor one located at a lower temperature. The major peak corresponds to denaturation of the $\beta$-lactoglobulin $(\beta-\lg )$, the major whey protein in our protein-rich product, and the minor peak to $\alpha$-lactalbumin ( $\alpha$-la) denaturation. Peak temperatures and $\mathrm{Q}_{\mathrm{cal}}$ values extracted from these DSC traces are reported in Table III. It is shown that $\mathrm{Q}_{\mathrm{cal}}$ values, which can be used as an indicator index of protein conformational stability [25], decreased by $\sim 50 \%$ and $\sim 30 \%$, when submitted, respectively, to spray-drying under high and mild air inlet temperatures, in comparison with untreated WP-L solution. As for the other protein characteristics, DSC results obtained from the three protein samples indicated different behaviours depending on their previous hydro-thermal treatment.

The mechanism of protein denaturation may be caused by alteration in its original native structure without hydrolysis of primary covalent bonds. It occurs following a first reversible step, where multimeric proteins may dissociate into monomeric forms, then denature within another or several successive unfolding steps, following the simplified scheme $[12,24]$ :

$$
\begin{array}{r}
\mathrm{N}_{\mathrm{x}} \text { (native) } \stackrel{\mathrm{K}_{\mathrm{eq}}}{<=}>\mathrm{xD}_{1} \stackrel{\mathrm{k}_{1}}{\rightarrow} \mathrm{xD}_{2} \stackrel{\mathrm{k}_{\mathrm{i}}}{\rightarrow} \\
\mathrm{xDi} \text { (denatured/unfolded states) } \stackrel{\mathrm{k}}{\rightarrow} \\
\text { A (aggregated). }
\end{array}
$$

Considering the simplified scheme represented above, if $\mathrm{k}>\mathrm{K}_{\mathrm{eq}}$, most of the denatured proteins can be converted irreversibly into aggregates and the thermal behaviour of the system is kinetically controlled by the rate-limiting step reaction. Following this mechanism, the increase in the major peak temperatures observed in the protein solutions WP-L, WP-P 85 and WP-P 138 could be explained by increasing values of the equilibrium constant $\left(\mathrm{K}_{\mathrm{eq}}\right)$, and increased concentration of denatured states (shift to the right of the equilibrium reaction). Aggregation and denaturation involve, respectively protein-protein interactions (exothermic reaction) and breaking up (endothermic reaction) of low energy amino acid linkages. They can be superimposed in the same temperature range, and the corresponding overall calorimetric energy, $\mathrm{Q}_{\mathrm{cal}}$, due to these heat-induced structural changes can be used to explain the decrease in heat involved during the DSC heating cycles.

Structural changes which are reflected in the loss of protein solubility, formation of covalently-bound aggregates and appearance of new fluorophore compounds are also reflected by the DSC results (Tab. III). They also indicated that spray-drying of whey proteins $(18.5 \%$ wt concentration-pH 6.7), prepared from skimmed milk by microfiltration, can lead to heat-induced denaturation-aggregation during their hydro-thermal path in the drying chamber. 


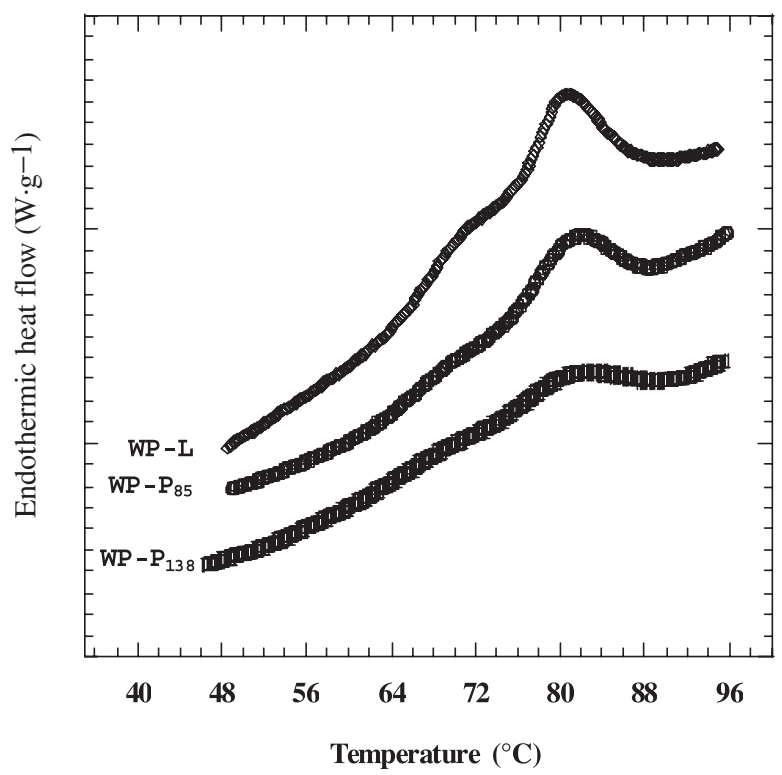

Figure 2. Thermograms obtained for whey protein solutions, before drying (WP-L) and from dispersions of spray-dried powder at $170 / 85^{\circ} \mathrm{C}\left(\mathrm{WP}-\mathrm{P}_{85}\right)$ and $260 / 138{ }^{\circ} \mathrm{C}\left(\mathrm{WP}-\mathrm{P}_{138}\right)$ air inlet/outlet temperatures.

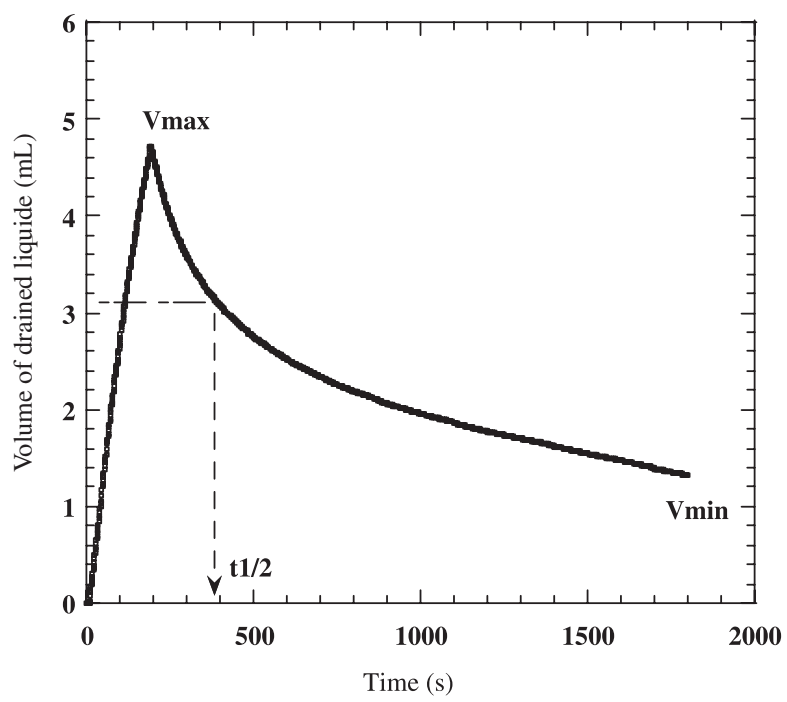

Figure 3. Example of liquid volume variation in a foam containing a whey protein sample, as measured by conductimetry during and after the air sparging periods. $t_{1 / 2}$ is the time corresponding to drainage of half of the liquid entrained in the foam during air sparging (see text). 

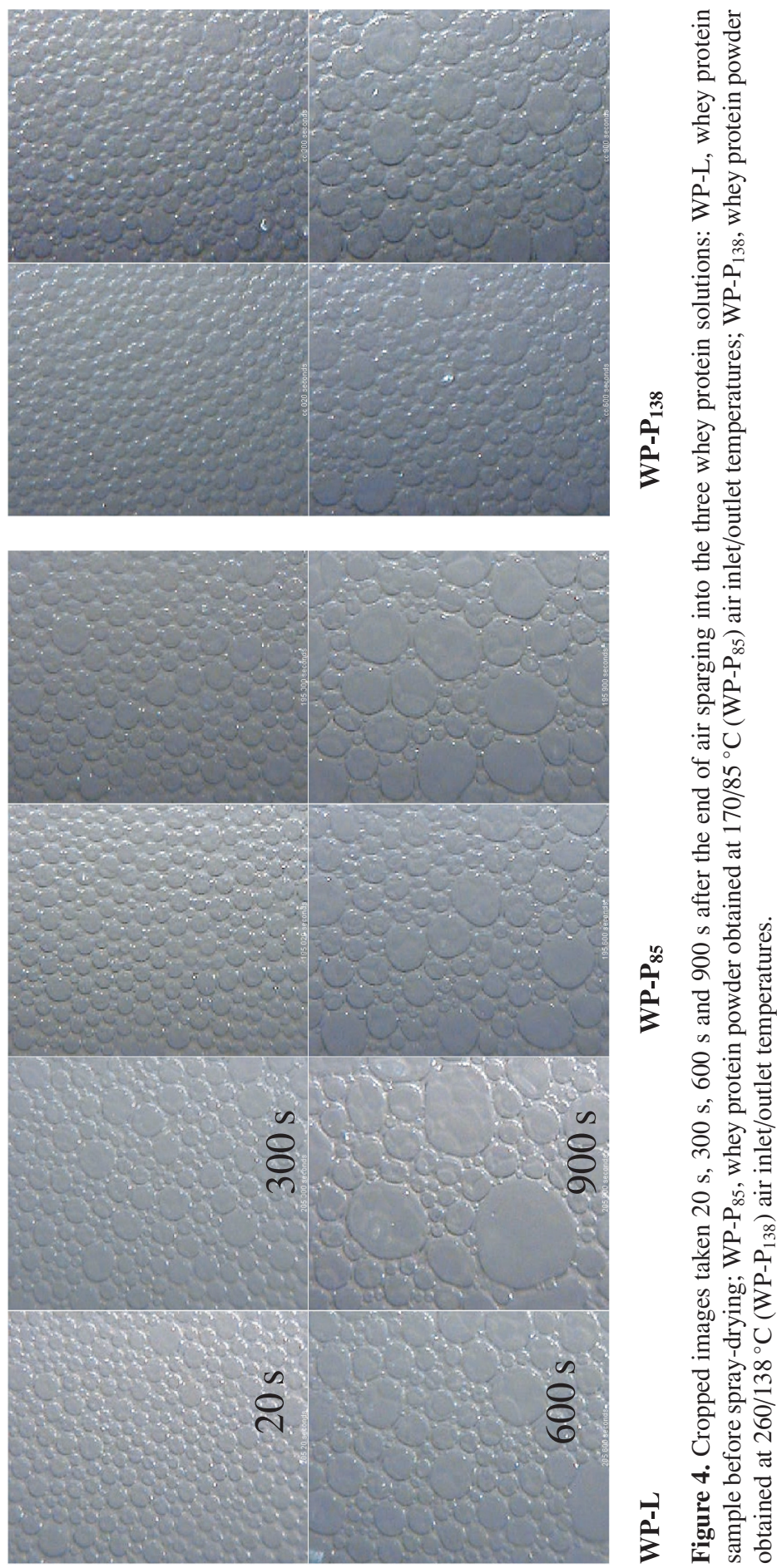
The formation of foams by air sparging in whey protein solutions $(0.5 \% \mathrm{NaCl})$, obtained from dilution of WP-L or dispersion of $\mathrm{WP}_{-} \mathrm{P}_{85}$ and $\mathrm{WP}-\mathrm{P}_{138}$ to $0.5 \mathrm{wt} \% \mathrm{wt}$ in distilled water, was monitored by conductimetric measurements. Examples of variation of liquid in foams evaluated following equation (2), during the air sparging period (foam formation) and the destabilisation period, are shown in Figure 3. In our experimental conditions, we observed that all of the three solutions required about the same bubbling time ( $\sim 3 \mathrm{~min})$ to attain a foam volume of $40 \mathrm{~mL}$, but the amount of liquid incorporated in the corresponding foams and the liquid drainage characteristics were different. Foam density values $\left(D_{\max }\right)$ reached at the end of air sparging, as evaluated from the maximum liquid volume $\left(\mathrm{V}_{\max }\right)$ entrained during air sparging, were similar for WP-L and WP-P 85 foams $\left(105 \mathrm{~g} \cdot \mathrm{L}^{-1}\right)$ and slightly higher $\left(119 \mathrm{~g} \cdot \mathrm{L}^{-1}\right)$ for WP-P 138 . As foam density in bubbling tests is inversely correlated to foam expansion in whipping tests [10], it appeared that spray-drying in high air temperature conditions enhanced the protein foamability. The stability of foams against liquid drainage, quantified relatively to WP-L solution through $\mathrm{t}_{1 / 2}$ values (Eq. (3)) was $\sim 12 \%$ and $\sim 18 \%$ higher for WP-P $\mathrm{P}_{85}$ and WP-P 138 foams, respectively. Proteins, to be good foaming agents, must be able to adsorb from bulk medium to the air-liquid interface and to entrap the gas bubbles in a continuous liquid lamellar phase. To be good foam stabilisers, adsorbed proteins must be able to prevent reduction in the liquid lamella thickness and close approach of bubbles, in the coalescence or growing of small bubbles by a disproportionation (gas diffusion between bubbles), and consequently in liquid drainage [9].

Time evolution of air bubble size and shape, as observed from cropped images taken at $20 \mathrm{~s}, 300 \mathrm{~s}, 600 \mathrm{~s}$ and $900 \mathrm{~s}$ after the end of air sparging (Fig. 4), seemed to follow trends related to foam characteristics, as evaluated from conductivity measurements. The images observed as a function of liquid drainage after the end of air sparging showed a lower increase in air bubbles' size in foam containing WP- $\mathrm{P}_{138}$, than in the foam containing WP-P 85 or WP-L, the latter protein solution being less resistant to liquid drainage and having a longer half liquid drainage time.

In earlier studies, it was shown that controlled mild heat treatment of globular proteins in controlled physico-chemical conditions can decrease their resistance to heat denaturation, with positive effects on their surface activity and stabilisation of protein-based foams $[11,13,23]$. In this work, we observed that despite a slight decrease in protein solubility and formation of a low proportion of covalentlybound aggregates, the decrease in whey proteins' conformational stability was accompanied by enhancement of their ability to stabilise foams. Thus, spray-drying in a co-current configuration of protein-rich products could be proposed as a new technological way to enhance end-use properties of whey proteins.

\section{REFERENCES}

[1] Anandharamakrishnan C., Rielly C.D., Stapley A.G.F., Thermal denaturation of whey proteins during spray-drying, in: Proceedings of the 15th International Drying Symposium, August 2006, Budapest, Hungary, 2006, pp. 1265-1272.

[2] Bernard C., Broyart B., Vasseur J., Relkin P., Production of whey protein powders with controlled end-use properties, in: Proceedings of the 15th International Drying Symposium, August 2006, Budapest, Hungary, 2006, pp. 1279-1286.

[3] Birchal V.S., Passos M.L., Wildhagen G.R.S., Mujumdar A.S., The influence of spray dryer operation variables on milk powder quality, in: Proceedings of the 14th International Drying Symposium, Sao Paulo, Brazil, 2004, pp. 389-396.

[4] Birlouez-Aragon I., Sabat P., Gouti N., A new method for discrimination milk heat treatment, Int. Dairy J. 12 (2002) 59-67. 
[5] Borios C., Lancelot J., Davenas P., Ilari J.L., Vérification industrielle de l'influence de certains paramètres technologiques de fabrication sur les propriétés physiques de la poudre de lait écrémé, Ind. Alim. Agric. (1984) 1211-1219.

[6] Dannenberg F., Kessler H.G., Reaction kinetics of the denaturation of whey proteins in milk, J. Food Sci. 53 (1988) 258-263.

[7] Donovan M., Mulvihill D.M., Thermal denaturation and aggregation of whey proteins, Ir. J. Food Sci. Technol. 11 (1987) 87-100.

[8] Galani D., Apenten R.K.O., Heat-induced denaturation and aggregation of $\beta$ lactoglobulin: kinetics of formation of hydrophobic and disulphide-linked aggregates, Int. J. Food Sci. Technol. 34 (1999) 467-476.

[9] Graham D.E., Phillips M.C., The conformation of proteins at the air-water interface and their role in stabilizing foams, in: Foams, Akers R.J. (Ed.), Academic Press, Boston, USA, 1976, pp. 237-255.

[10] Guillerme C., Loisel W., Bertrand D., Popineau Y., Study of foam stability by video image analysis: relationship with the quantity of liquid in foams, J. Texture Stud. 24 (1993) 287-303.

[11] Hagolle N., Relkin P., Popineau Y., Bertrand D., Study of the stability of egg white protein-based foams: effect of heating protein solution, J. Sci. Food Agric. 80 (2000) $1245-1252$.

[12] Harwalkar V.R., Ma C.Y., Thermal analysis of foods, Elsevier Applied Science Publisher, London, UK, 1990.

[13] Marin I., Relkin P., Foaming properties of $\beta$-lactoglobulin: impact of pre-heating and addition of isoamyl acetate, Int. J. Food Sci. Technol. 34 (1999) 515-522.

[14] Masters K., Spray drying in practice, SprayDryConsult International Aps, Denmark, 2002.

[15] Millqvist-Fureby A., Elofsson U., Bergenstähl B., Surface composition of spray-dried milk protein-stabilized emulsions in relation to pre-heat treatment of proteins, Coll. Surface B: Biointerfaces 21 (2001) 47-58.
[16] Mills O.E., Effect of temperature on tryptophan fluorescence of $\beta$-lactoglobulin, Biochem. Biophys. Acta 434 (1976) 324-332.

[17] Morales F.J., Romero C., Jimenez-Perez S., Fluorescence associated with Maillard reaction in milk and milk-resembling systems, Food Chem. 57 (1996) 423-428.

[18] Morr C., Ha E.Y.W., Whey protein concentrates and isolates: processing and functional properties, Food Sci. Nutr. 33 (1993) 431476.

[19] Nijdam J.J., Langrish T.A.G., The effect of surface composition on the functional properties of milk powders, J. Food Eng. 77 (2006) 919-929.

[20] Oldfield D.J., Taylor M.W., Singh H., Effect of preheating and other process parameters on whey protein reactions during skim milk powder manufacture, Int. Dairy J. 15 (2005) 501-511.

[21] Pisecky J., Spray drying in the cheese industry, Int. Dairy J. 15 (2005) 531-536.

[22] Privalov P.L., Potekin S.A., Scanning calorimetry in studying temperature induced changes in proteins, Methods Enzymol. 131 (1996) 4-51.

[23] Relkin P., Using DSC for monitoring protein conformation stability and effect of fat droplets crystallinity in complex food emulsions, in: Lörinczy D. (Ed.), The nature of biological systems as revealed by thermal analysis, Kluwer Academic Publishers, London, UK, 2004, pp. 99-126.

[24] Relkin P., Launay B., Concentration effects on the kinetics of $\beta$-lactoglobulin heat denaturation: a differential scanning calorimetric study, Food Hydrocoll. 4 (1990) 19-32.

[25] Relkin P., Hagolle N., Dalgleish D.G., Launay B., Foam formation and stabilisation by pre-denatured ovalbumin, Coll. Surface B: Biointerfaces 12 (1999) 409-416.

[26] Sourdet S., Relkin P., César B., Structuration of complex food emulsions by pre-heated milk proteins, Coll. Surface B: Biointerfaces 31 (2003) 55-64. 